Metal exposure to a benthic invertebrate, Hydropsyche californica, in the Sacramento River downstream of Keswick Reservoir, California

By Daniel J. Cain, James L. Carter, Steven V. Fend, Samuel N. Luoma, Charles N. Alpers and Howard E. Taylor

U.S. Geological Survey Open Flle Report 98-654

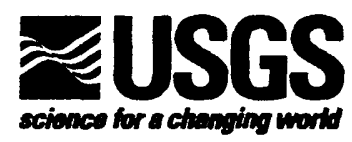




\section{U.S. Department of the Interior \\ Bruce Babbitt, Secretary}

\section{U.S. Geological Survey \\ Charles G. Groat, Director}

Any use of firm, trade, and brand names is for identification purposes only and does not const ${ }^{t} u t e$ endorsement by the U.S. Government

For additional information write to:

Daniel J. Cain

U.S. Geological Survey

Water Resources Division, MS 465

Menlo Park, CA 94025
Copies of this report can be obtained from the authors or:

U. S. Geological Survey Information Services Box 25286, MS 517 Denver Federal Center Denver, CO 80225 


\section{Contents}

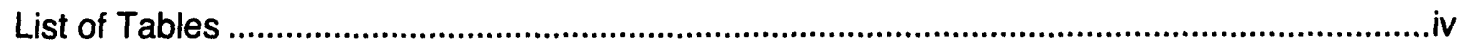

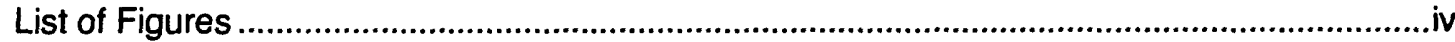

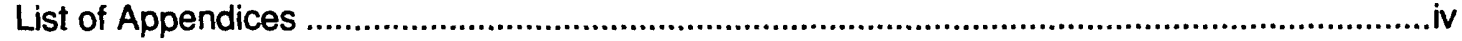

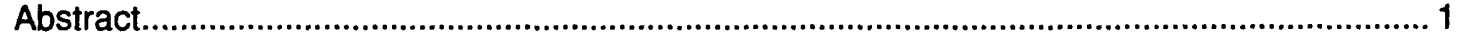

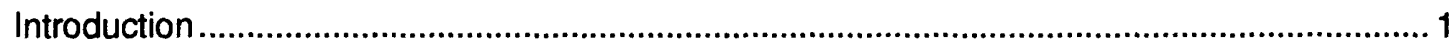

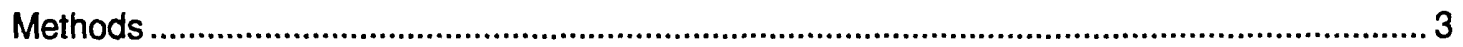

Sample Collection .................................................................................................. 3

Sample Preparation .......................................................................................... 5

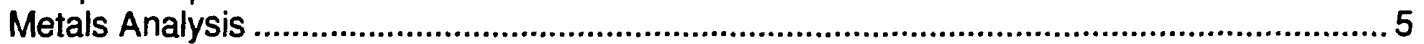

Quality Assurance ...............................................................................................6 6

Data Analysis ................................................................................................6

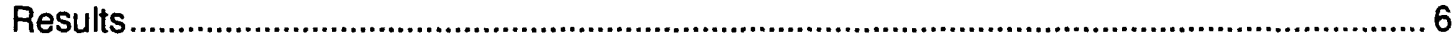

Metal Enrichment in the Sacramento River ............................................................6 6

Metal Partitioning in the Insect ............................................................................. 8

Spatial patterns in Whole-Body Metal Concentrations.....................................................9

Spatial Patterns in Enriched, Cytosolic Metals......................................................... 10

Discussion ............................................................................................................11

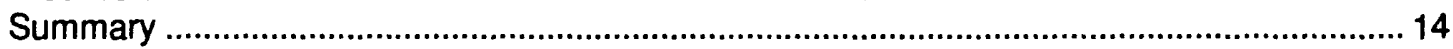

Acknowledgements ............................................................................................... 14

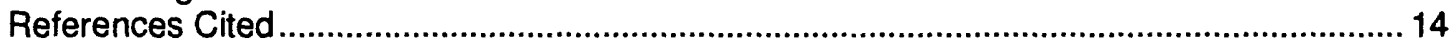

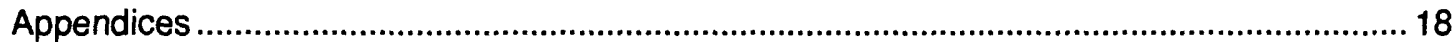




\section{List of Tables}

1. Metal concentrations and enrichment factors in $\mathrm{H}$. californica collected from the Sacramerto River and Cottonwood Creek in October 1996.

2. The percent of the total metal body burden contained in the cytosol of $H$. californica. .8

\section{List of Figures}

1. Map of the study area names, numerical designations, and locations of stations in the upper Sacramento River and Cottonwood Creek where $\mathrm{H}$. californica were collected in October 1996.

2. Plots showing the correlations between the mean whole-body and cytosolic metal concentrations in $\mathrm{H}$. californica from stations in the upper Sacramento River and Cottonwood Creek during October 1996.

3. The mean whole-body and cytosolic metal concentrations in $H$. californica plotted by station.

\section{List of Appendices}

1. The names, numerical designations, and locations of stations sampled for Hydropsyche californica in October 1996

2. Operating conditions for the inductively coupled plasma - mass spectrometer....

3. Comparison of metal concentrations determined in the study with the certified values repcrted by the National Institute of Standards and Technology for SRM 1566a, oyster tissue, and RM 50, albacore tuna, and by the National Research Council Canada for Tort 2, lobster hepatopancreas,

and Dorm 2, dogfish muscle 20 


\title{
Metal exposure to a benthic invertebrate, Hydropsyche californica, in the Sacramento River downstream of Keswick Reservoir, California
}

\author{
By Daniel J. Cain, James L. Carter, Steven V. Fend, Samuel N. Luoma, Char'os \\ N. Alpers and Howard E. Taylor
}

\begin{abstract}
Metals ( $\mathrm{Al}, \mathrm{Cd}, \mathrm{Cu}, \mathrm{Fe}, \mathrm{Hg}, \mathrm{Pb}$, and $\mathrm{Zn}$ ) were determined in a resident, invertebrate species to assess the occurrence and distribution of biologically available metal along a $111 \mathrm{~km}$ section of the upper Sacramento River affected by acid mine drainage. Samples of the filter-feeding caddisfly Hydropsyche californica (Insecta: Trichoptera) were collected from five stations in the Sacramento River between Redding and Tehama, California. Metal concentrations in these samples were referenced to samples from an uncontaminated tributary, Cottonwood Creek. Aluminum, $\mathrm{Cd}, \mathrm{Cu}, \mathrm{Fe}, \mathrm{Pb}$, and $\mathrm{Zn}$ in the body of the insect were separated into cytosolic (soluble) and particulate components. The cytosol is an intracellular metal fraction and therefore, an indicator of metal bioavailability. The concentrations and the relative proportions of metals in the cytosol identified differences in bioaccumulation among metals and characterized spatial patterns of bioavailable metals. Total $\mathrm{Hg}$ was determined in the whole body, but not the cytosol. Results showed that concentrations of $\mathrm{Cd}, \mathrm{Cu}, \mathrm{Pb}$, and $\mathrm{Zn}$ in the whole body, and both the particulate and cytosolic fractions of Hydropsyche from the Sacramento River were significantly greater than in those from the reference site. Enrichment of $\mathrm{Cd}$ was greater than the other metals, exceeding the Cd reference concentration by nearly 20 fold at the most upstream station. Concentrations of $\mathrm{Hg}$ and $\mathrm{Fe}$ in caddisflies were not elevated. Aluminum concentrations were elevated in the cytosol, only. This enrichment was not evident in the whole body because cytosolic Al accounted for less than 1 percent of the total body burden. The vast majority of $\mathrm{Al}$ was associated with undigested gut content, the exoskeleton, and other structures associated
\end{abstract}

with the particulate fraction. Concentrations in this fraction were not enriched. Likewise, only a minor fraction of the total $\mathrm{Fe}$ an $\mathrm{P} \mathrm{Pb}$ were associated with the cytosol. In contrast, a high proportion of the $\mathrm{Cd}, \mathrm{Cu}$, and $\mathrm{Zn}$ in Hydropsyche sp. were conte ined in the cytosol, indicating that these matals were biologically available. Maximum concentrations of cytosolic $\mathrm{Cd}, \mathrm{Cu}, \mathrm{Pb}$, and Al occurred at the three most upstream stations (river km 479-444) and decreased downstream to Tehama (river $\mathrm{km} \mathrm{368),}$ although a small increase in bioavailable $\mathrm{Cd}$ and $\mathrm{Cu}$ was observed at Bend Bridge (river $\mathrm{km} \mathrm{415).} \mathrm{Except} \mathrm{for} \mathrm{a} \mathrm{small} \mathrm{increase} \mathrm{in}$ cytosolic $\mathrm{Zn}$ at Bend Bridge, $\mathrm{Zn}$ concentrations did not atteruate downstream, but instead were unifc rmly elevated throughout the $111 \mathrm{~km}$ section. At Tehama, concentrations of cytosolic Al, Cd, $\mathrm{Cu}, \mathrm{Pb}$, and $\mathrm{Zn}$ were 1.5 to 5 times grnater than reference concentrations from Cottonwood Creek, suggesting that transport of bioavailable forms of these metals extended downstream of Tehama. The results indicate that Hydropsyche in the upper Sacramento River were exposed to elevated concentrations of bioavailable $\mathrm{Al}$, $\mathrm{Cd}, \mathrm{Cu}, \mathrm{Pb}$, and $\mathrm{Zn}$. Distribution patterns of bioavailable $\mathrm{Al}, \mathrm{Cd}, \mathrm{Cu}$, and $\mathrm{Pb}$ were consistent with documented sourcer of metal from the East Shasta and $14 / e$ t Shasta mining districts, upstream of Redding.

\section{Introduction}

Drainage from base-metal miness at Iron Mountain in northern California is a source of metals to the Sacramento Piver that has threatened resident fauna (Shaw, 1940; Finlayson and Ashuckian, 1979; Finlayson and Wilson, 1979; Finlayson and Verrue, 1980; NOAA, 1989). Recurring fish kills (USEPA, 1992) prompted the construction of the Spring Creek Debris Dam 
(SCDD) in 1963 to abate the discharge of metal-laden acid mine water from Spring Creek into the Sacramento River (fig. 1). In addition, water is treated with lime to precipitate metals. A temporary lime neutralization plant operated 3 to 4 months per year during 1989-1993. Since July 1994, there has been continuous, year-round, treatment. Treatment has reduced annual metal loadings of $\mathrm{Cu}$ by about $80-85$ percent and $\mathrm{Zn}$ (and probably cadmium also) by about 90 percent. Prior to lime neutralization treatment, about 90 percent of the $\mathrm{Cu}$ loading to the Sacramento River at Keswick Dam could be attributed to Spring Creek and the Iron Mountain mine drainage (D. Heiman, State of California Regional Water Quality Control Board, Sacramento, CA, unpublished data). Since 1994, this component of the overall $\mathrm{Cu}$ loading has been reduced to about 50 percent. The remainder is predominantly from other mines in the West Shasta mining district that drain into Shasta Lake via Little Backbone Creek and West Squaw Creek (D. Heiman, unpublished data).

Flows from the SCDD are regulated by the Bureau of Reclamation, together with dilution flows from Shasta Lake and Whiskeytown Lake (via the Spring Creek Power Plant), to meet water-quality criteria for the protection of resident fish at a compliance point below Keswick Dam (fig. 1). Nevertheless, these water-quality criteria are sometimes exceeded during times of heavy rainfall when water in the Spring Creek Reservoir overtops the SCDD and insufficient dilution flows are available. In addition, the operation of the SCDD increases the total duration of exposure of fish to metals at chronically toxic concentrations (USEPA, 1992).

The aquatic habitat in the section of the Sacramento River between Keswick Dam and Red Bluff is of special concern because it includes spawning ground for several salmonid fish species, including four distinct runs of chinook salmon (Oncoryhnchus tshawytscha), plus steelhead trout and resident rainbow trout (O. mykiss) (USEPA, 1992). The winter-run chinook salmon is a Federally listed endangered species, and the steelhead trout and one or more of the other chinook salmon runs recently have been listed as threatened species (NOAA, 1994; 1997). A study of metals in livers from trout b?low Keswick Dam (Wilson and others, 1981) showed elevated concentrations of $\mathrm{Cd}, \mathrm{Cu}$, and $\mathrm{Zn}$, at possibly harmful levels. A more recent survey (1990) indicated a general contamination of the aquatic food web in the Sacramento River downstream of Kesivick Reservoir to Jelly's Ferry, located above Red Bluff (Saiki and others, 1995). However, the downstream extent of contamination has not been fully resolved, and little is krown specifically about the biological availability of metals within the river.

Benthic insects are one groun of organisms used to monitor metal exposures and assess biological effects in freshwaters (Cain and others, 1992; Hare, 1992; Rosenberg and Resh, 1993). Assessments of biological risk associated with exposure are strengthened when methods allow distinction between metal that is taken up and accumulated within cells from metal that occurs extracellularly. The latter includis a variety of forms that probably pose little toxic risk (e.g. metals or metal-bearing partiles on external body parts and metals retained with undigested material in the gut of the animal). Recently, Cain and Luoma (1998) evaluated metal exposures in a miningimpacted river by determining metal concentrations of the cytosol (the soluble portion of the cell cytoplasm) in an aquatic insect.

Metal analysis of the cytosol ar $1 /$ or other intracellular components provides an unambiguous indicator of metal bioavailability. The cytosol appears to b? an important accumulation site for essential metals such as $\mathrm{Cu}$ and $\mathrm{Zn}$ and certain nonessential elements, including Cd (Seidman and others, 1986; Suzuki and others; 1988; Cain and Luoma, 1998). Furthermore, sublethal effects have been showr to coincide with accumulation of $\mathrm{Cd}$ in the cytosol and redistribution of $\mathrm{Cd}$ amnng cytosolic ligands (Jenkins and Mason, 15 ?8). Therefore, concentrations of cytosolic metals reflect intracellular dose, and may bo a better diagnostic of toxicity than $e^{\text {ther }}$ whole-body or whole-tissue concentrations (Roesijadi, 1994; Thorp and Costlow, 1989).

Saiki and others (1995) showed that metals contaminate fish and some of their prey species in the Sacramento $\mathbf{R}$ 'er, implying that food was a potential source of metals to the fish. The transfer of motals 
through food webs may be influenced by how metals are constituted in the body of prey species. Cytosolic metal appears to be a biologically available component of food. Reinfelder and Fisher (1991) demonstrated that the efficiency of metal absorption by copepods fed metal-contaminated algae was directly proportional to metal in the cytosolic fraction of the algae. Although such simple relationships are not always observed (Lee and Luoma, 1998), studies with predators and their prey suggest that the cytosolic metal fraction is one component of dietary exposure (Reinfelder and Fisher, 1994; Wallace and Lopez, 1997). In contrast, metals that are encased in intracellular inclusions, such as calcium or phosphaterich granules, are not efficiently digested by predators, and are passed intact through the digestive tract (Nott and Nicolaidou 1990). Similarly, other particulate forms of metal that reside outside the cell, such as those sorbed to external body parts and bound to undigested gut content, may be largely unavailable to higher trophic organisms. Thus, an analysis of metal partitioning in prey species may help identify metals most likely to be accumulated from food.

This study was conducted in conjunction with a broader study of the distribution, geochemistry, and transport of metals in the Sacramento River (Alpers and others, 2000a; 2000b). The principal objective of this study was to assess the occurrence and distribution of biologically available metals in the upper Sacramento River, below Keswick Reservoir. Also, because of the concern for resident fish, there was a need for data that were at least broadly indicative of dietary metal exposure to fish in the upper Sacramento River.

$$
\text { Metal contamination and }
$$

bioavailability was assessed by comparative analysis of metal concentrations in the hydropsychid caddisfly, Hydropsyche (Insecta: Trichoptera). This taxon has been successfully used in metal contamination studies (Cain and others, 1992; Axtmann and others, 1997; Vuori and Kukkonen 1996). The larva is a filter-feeding organism that uses a silken mesh to sieve suspended particles from solution. The larva has a sedentary life stage of about 1-year, is relatively metal tolerant (Clements and others, 1992), and is widely distributed and abundant in many rivers, including the Sacramento River. Partitioning of motals between the cytosol and the whole body was useful in identifying differences in bioavailability among metals. The concentrations and spatial distributions of bioavailable metals were evaluated from the cytosol of Hydropsyche sampled from five stations in the Sacramento River ard a reference station on Cottonwood Creek, a tributary to the Sacramento River near Redding (fig. 1). Total $\mathrm{Hg}$ concentrations were determined in the whole body, but not the cytosol, of Hydropsyche to assess the occurrence of $\mathrm{Hg}$ contamination in the upper Sacramento River. Consumption of motalcontaminated benthic macroinvertebrates including Hydropsyche can be a significant cause of chronic metal contamination in resident fish (Woodward and others, 1995; Farag and others, 1995). Therefore, dintary exposure to fish was assessed from metals concentrations in Hydropsyche, esperially those associated with the cytosol.

\section{Methods}

\section{Sample Collection}

Samples of Hydropsyche lavae were collected at five stations in the Sacramento River within a $111 \mathrm{~km}$ section between Rodeo Park near Redding (rive- $\mathrm{km}$ 479) and Tehama (river $\mathrm{km} \mathrm{368)} \mathrm{(fic.} \mathrm{1;}$ appendix 1). Stations were sampled during a period of low-flow conditions on Oct sber 21-23, 1996. In addition, a sample was collected from Cottonwood Creek, near Cottonwood (river km 439) (fig. 1; appendix 1). This sample was used as a local reference to evaluate metal levels in samples from the Sacramento River. Samples were not collected upstrean of Keswick Reservoir, downstream of Tehama or during other times of the year because of the scarcity of habitat that could be samuled using the methods we emplo"sd. Hydropsyche larvae were collected with large kick nets and by hand from a single, wadeable (approximately 0.3 meter disep) riffle at each station. 


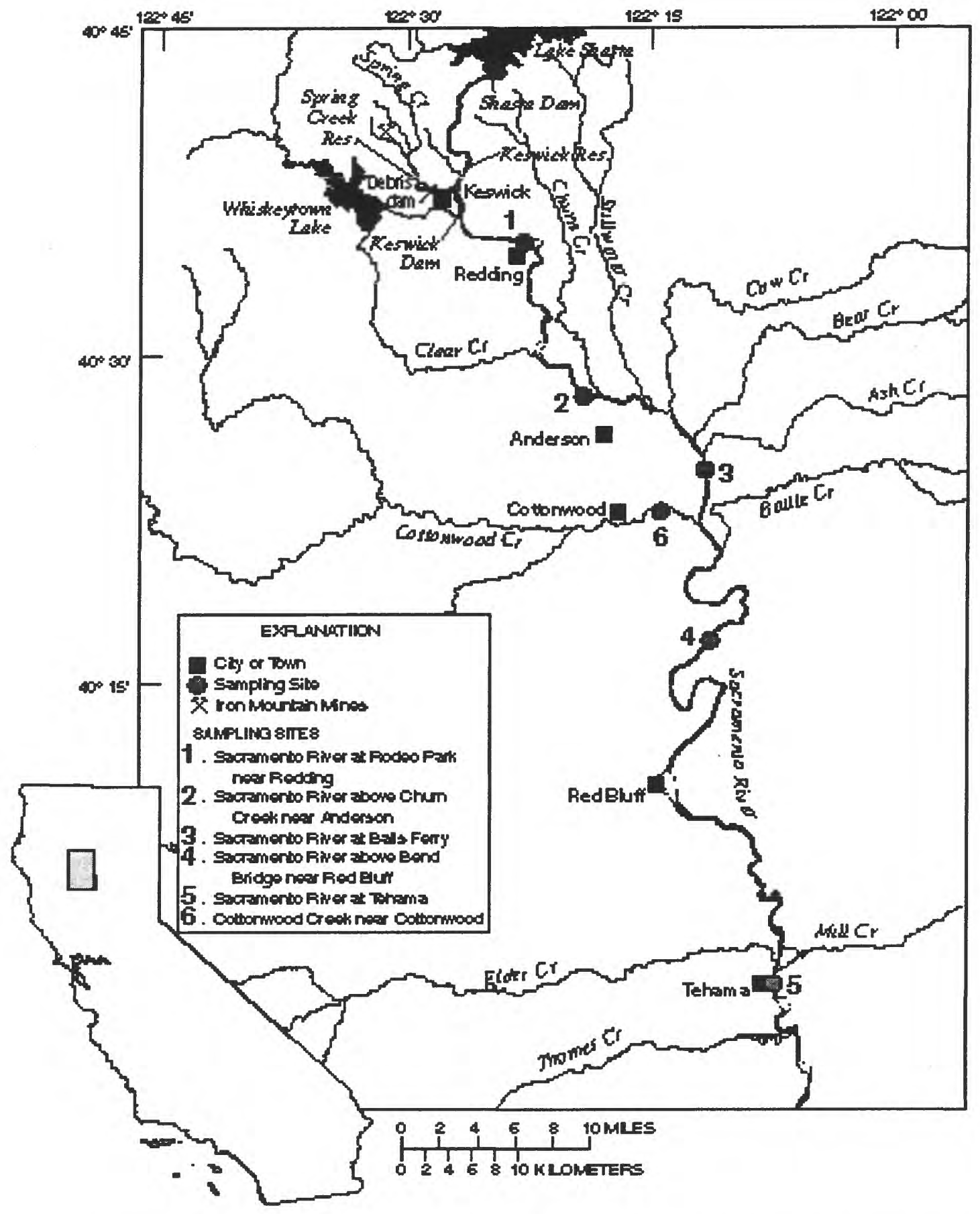

Figure 1. Map of the study area names, numerical designations, and locations of stations in the upper Sacramento River and Cottonwood Creek where Hydropsyche californica were collected in October 1996. 
Specimens were picked from the net with nylon forceps and placed into plastic trays with stream water (forceps and trays were previously acid washed). Water in the trays was freshened periodically. Specimens were transferred from the trays to plastic, sealed bags and frozen on dry ice in a small volume of river water within 1 hour of collection. The samples were moved to the laboratory where they were stored at $-70^{\circ} \mathrm{C}$ until sample preparation. Additional specimens for taxonomic identification were preserved in 10 percent formalin in the field and transferred to 75 percent ethanol in the laboratory. Samples were dominated by a single species, Hydropsyche californica.

\section{Sample Preparation}

Samples for the determination of aluminum (Al), cadmium (Cd), copper (Cu), iron $(\mathrm{Fe})$, lead $(\mathrm{Pb})$, and zinc $(\mathrm{Zn})$ were prepared following the method described by Cain and Luoma (1998). Specimens were partially thawed in batches, rinsed with cold deionized water to remove sediment and detritus, and then transferred to a glass, sorting dish that was placed on a bed of ice. The animals were immersed in a small amount of water and viewed individually under a stereomicroscope for identification and further cleaning. Instars of $H$. californica were not sorted, although smaller specimens that could not be identified were discarded. Specimens were then transferred to a cooler. When the entire sample had been sorted and cleaned, the animals were, blotted dry with tissue paper, pooled into replicate subsamples $(n=4-6)$ of approximately the same wet weight, and then temporarily refrigerated.

Cold $0.05 \mathrm{M}$ Tris- $\mathrm{HCl}$ buffer $(\mathrm{pH} 7.4$, previously degassed by vacuum and then bubbled with $\mathrm{N}_{2}$ ) was added to each subsample at a ratio of $8: 1$ (milliliters Tris:gram wet sample). Subsamples were homogenized with a stainless-steel highspeed tissue homogenizer under a nitrogen atmosphere for one minute. The homogenate was split into two fractions: one for the whole-body metal analysis and the other for the cytosolic metals. The cytosol was isolated by centrifuging the homogenate at $100,000 \times \mathrm{g}$ for 1 hour at $5^{\circ} \mathrm{C}$. The supernatant (cytosol) and pellet were collected and transferred to separate screw- cap glass vials. Samples were kept cold throughout the procedure. Sample fractions were frozen at $-20^{\circ} \mathrm{C}$ as they were prepered. Later, they were freeze-dried, weighed, digested by reflux in hot, isopiestirally distilled (Kuehner and others, 1972) $16 \mathrm{~N}$ $\mathrm{HNO}_{3}$. When the digestion was comp'ote, the samples were evaporated to dryness.

Prior to analysis, sample residues were reconstituted by the addition of 10 milliliters (ml) of 1 percent high-purity $\mathrm{HI}^{\prime} \mathrm{O}_{3}$. Five $\mathrm{ml}$ of this solution was diluted to $5 ? \mathrm{ml}$ for trace metal analysis.

All plastic and glassware usec' for the preparation and digestion was clecned by soaking overnight in a Micro ${ }^{2}$ solution, rinsed with deionized $\mathrm{H}_{2} \mathrm{O}$, then washed in 5 percent $\mathrm{HCl}$ and rinsed with deionized $\mathrm{I}_{2} \mathrm{O}$. The tissue homogenizer was cleanec' by soaking overnight in a solution of RBSB and rinsed in deionized $\mathrm{H}_{2} \mathrm{O}$.

Additional samples from all stations were sorted and cleaned as described atove for the determination of mercury $(\mathrm{Hg})$. Samples were composed of single or duplicate subsamples, which were frozen at $-20^{\circ} \mathrm{C}$ immediately. The subsamples were freeze dried and then homogenized with a mixer-mill using $125 \mathrm{ml}$ polycarbonate jars and methacrylate balls. Samples were digested following the procedure described by Elrick and Horowitz (1986).

\section{Metals Analysis}

Aluminum, $\mathrm{Cd}, \mathrm{Cu}, \mathrm{Pb}$ and $\mathrm{Zn}$ in the digested samples were determined by inductively coupled plasma-mass spectrometry (ICP-MS), using a modifice tion of a direct analysis procedure reported by Taylor and Garbarino (1991) and Garbarino and Taylor (1994). All of trese determinations were performed with a Perkin-Elmer Sciex, Model 5000 inductively coupled plasma-mass spectrometer fitted with a gem-cone@ pneumatic nebulizer. Instrument operating conditions and specific isotopes used for measurement are list $€ d$ in appendix 2.

Iron was determined by a mod"ied inductively coupled plasma-atomic emis-ion spectrometric (ICP-AES) technique (Taylor and Garbarino, 1985) at a wavelength of $259.94 \mathrm{~nm}$. Measurements were made with a Thermal Jarrell-Ash model 975 atcmic emission spectrometer using a U.S. 
Geological Survey designed Babington-type pneumatic nebulizer (Garbarino and Taylor, 1980).

Mercury was determined by cold vapor atomic absorption spectrophotometry using conditions described by Elrick and Horowitz (1986).

\section{Quality Assurance}

In addition to the previously described, independently processed subsamples collected at each location, laboratory determinations for $\mathrm{Al}, \mathrm{Cd}, \mathrm{Cu}, \mathrm{Fe}$, $\mathrm{Pb}$, and $\mathrm{Zn}$ were performed in triplicate. Single or duplicate determinations of $\mathrm{Hg}$ were performed. Standard deviations reported for sample concentrations represent the combined precisions associated with sample collection, processing, and analysis.

Accuracy was established by the analysis of Standard Reference Materials obtained from the National Institute of Standards and Technology (NIST) and the National Research Council Canada (NRC). Four materials were selected to simulate invertebrate tissue: NIST SRM 1566a oyster tissue, NIST RM50, albacore tuna, NRC Tort -2 , lobster hepatopancress, and NRC Dorm - 2, dogfish muscle. Standards were processed in a manner identical to the procedure used for the invertebrate specimens. Results obtained for the analysis of these reference materials are given in appendix 3 . In addition, selected representative samples were spiked with a standard containing $\mathrm{Cd}, \mathrm{Cu}, \mathrm{Pb}$, and $\mathrm{Zn}$ prior to sample processing to establish their recovery during sample handling and analysis. The median (and range) of spike recoveries was 98 (95 to 102) percent for Cd, 94 (82 to 100) percent for $\mathrm{Cu}, 93$ (87 to 98) percent for $\mathrm{Pb}$, and 96 (93 to 108) percent for $\mathrm{Zn}$.

Procedural and reagent blanks were analyzed to evaluate potential contamination problems during sample processing and analysis. Appropriate reagent blank concentration values were used to correct the chemical analyses where necessary.

\section{Data Analysis}

The mean, standard deviation, and standard error of composite caddisfly samples ( $n=4-6$ for all samples except those analyzed for $\mathrm{Hg} \mathrm{n=1-2)}$ from each station were calculated. The number of replicates (n) generally reflected the abundance of $H$. californica at each station. Enrichment factors were calculated by dividing the mean metal concentrations of stations in the Sacramento River by the mean metal concentrations of the sample from Cottonwood Creek. The percent of metal recovered in the cytosol was calculated by dividing the metal concentration of the cytosol by the whole-body metal concentration and multiplying the result by 100. Differences in metal concentrations among stations were determined by single classification ANOVA, after the data were log transformed to correct for heteroscedasticity. Specific station comparisons were analyzed by the Turkey honest significant differences test for unequal sample sizes. Data that were not corrected by log transformation were analyzed by the Kruscal-Wallis ANOVA. Pearson product-moment correlations were determined between whole-body and cytosolic metal concentrations using the mean sample concentrations to avoid any bias due to unequal sample sizes (even though within station variance was much less that among station variance). Results of statistical tests were consic'sred significant if $\alpha<0.05$.

\section{Results}

Metal Enrichment in the Sacramento River Mean concentrations of $\mathrm{Cd}, \mathrm{Cu}, \mathrm{Pb}$, and $\mathrm{Zn}$ in the whole body, pellet, and the cytosol of Hydropsyche from all stations in the Sacramento River were significantly greater than in those from Cottoni"ood Creek, the reference site (table 1). Aluminum concentrations in the cytosol also were significantly higher in samples from the Sacramento River; however, concentrations in the whole body (and pellet) were significantly different than Cottonwood $\mathrm{C}$ "eek at Bend Bridge and Tehama, only. Iron concentrations of all body fractions in Sacramento Rive samples were variable, but were not either uniformly higher or lower than concentrations at Cottonwood Creek. Mercury concentrations in samples from the Sacramento River were $\leq 0.06 \mu \mathrm{g} / \mathrm{g}$, and lower than the concentration of the sample from Cottonwood Creek. Among the motals analyzed, Cd showed the greatest degrie of 
enrichment (Sacramento River / Cottonwood Creek). Enrichment factors for other metals in the whole body and the pellet followed the order $\mathrm{Cu}>\mathrm{Pb}>\mathrm{Zn}>\mathrm{Al}$. Relative to Cottonwood Creek, $\mathrm{Al}$ and $\mathrm{Pb}$ were more enriched in the cytosol than in the vihole body. Therefore, the order of enrichment in the cytosol was $\mathrm{Cd}>\mathrm{Pb}>\mathrm{Al} \geq \mathrm{Cu}>\mathrm{Zn}$.

Table 1. Metal concentrations in Hydropsyche californica collected from the Sacramento River and Cottonwond Cr. during October 21-23, 1996. Values are the mean \pm 1 standard deviation $(n=1-6 ;$ units are $\mu g / g$ dry weight). Metal enrichment factors (EF) in the Sacramento River (metal concentration of Sacramento River station/metal concentra*ion in Cottonwood $\mathrm{Cr}$.) are shown. Ne designates "not enriched" (i.e. enrichment factor was less than 1).

\begin{tabular}{|c|c|c|c|c|c|c|c|c|}
\hline \multirow[t]{2}{*}{ Element } & \multirow{2}{*}{$\begin{array}{l}\text { Body } \\
\text { Fraction }\end{array}$} & \multirow[b]{2}{*}{ Rodeo Park } & \multirow[b]{2}{*}{ Churn Cr. } & \multicolumn{2}{|l|}{ Station } & \multirow[b]{2}{*}{ Tehama } & \multirow[b]{2}{*}{$\begin{array}{l}\text { Cottonwnod } \\
\mathrm{Cr} \text {. }\end{array}$} & \multirow[t]{2}{*}{ EF } \\
\hline & & & & Balls Ferry & Bend $\mathrm{Br}$. & & & \\
\hline \multirow[t]{3}{*}{ Al } & Whole body & $1240 \pm 50$ & $1350 \pm 60$ & $1300 \pm 40$ & $1940 \pm 40$ & $2110 \pm 110$ & $1360 \pm 16 ?$ & $0.9-1.6$ \\
\hline & Cytosol & $10 \pm 1$ & $8 \pm 0.4$ & $11 \pm 2$ & $6 \pm 1$ & $6 \pm 1$ & $3 \pm 0.4$ & $2.0-3.7$ \\
\hline & Pellet & $960 \pm 150$ & $1420 \pm 87$ & $1270 \pm 80$ & $1720 \pm 130$ & $1710 \pm 80$ & $1130 \pm 110$ & $0.8-1.5$ \\
\hline \multirow[t]{3}{*}{$\mathrm{Cd}$} & Whole body & $2.16 \pm 0.10$ & $0.96 \pm 0.05$ & $0.77 \pm 0.08$ & $1.14 \pm 0.09$ & $0.66 \pm 0.02$ & $0.06 \pm 0.0=$ & $11-36$ \\
\hline & Cytosol & $1.27 \pm 0.09$ & $0.55 \pm 0.04$ & $0.52 \pm 0.14$ & $0.73 \pm 0.05$ & $0.36 \pm 0.02$ & $0.07 \pm 0.0^{4}$ & $5.1-18$ \\
\hline & Pellet & $0.94 \pm 0.23$ & $0.41 \pm 0.02$ & $0.33 \pm 0.04$ & $0.52 \pm 0.04$ & $0.30 \pm 0.02$ & $\leq 0.02$ & $\geq 15-47$ \\
\hline \multirow[t]{3}{*}{$\mathrm{Cu}$} & Whole body & $37.5 \pm 3.2$ & $37.7 \pm 1.6$ & $25.0 \pm 1.3$ & $30.8 \pm 2.5$ & $25.6 \pm 1.2$ & $14.5 \pm 0.4$ & $1.7-2.6$ \\
\hline & Cytosol & $20.7 \pm 1.1$ & $20.8 \pm 1.0$ & $14.1 \pm 0.3$ & $16.8 \pm 1.3$ & $12.1 \pm 0.9$ & $6.9 \pm 0.4$ & $1.8-3.0$ \\
\hline & Pellet & $15.3 \pm 6.0$ & $18.4 \pm 1.3$ & $12.1 \pm 0.8$ & $16.2 \pm 1.3$ & $14.0 \pm 0.6$ & $7.8 \pm 0.6$ & $1.6-2.4$ \\
\hline \multirow[t]{3}{*}{$\mathrm{Fe}$} & Whole body & $1460 \pm 150$ & $2070 \pm 50$ & $1340 \pm 320$ & $1970 \pm 590$ & $2830 \pm 190$ & $1860 \pm 207$ & $0.7-1.5$ \\
\hline & Cytosol & $45 \pm 2$ & $57 \pm 9$ & $65 \pm 5$ & $78 \pm 8$ & $55 \pm 7$ & $69 \pm 10$ & $0.7-1.1$ \\
\hline & Pellet & $1360 \pm 390$ & $1990 \pm 70$ & $1470 \pm 160$ & $1880 \pm 360$ & $2740 \pm 240$ & $1880 \pm 80$ & $0.7-1.5$ \\
\hline $\mathrm{Hg}$ & Whole body & 0.040 & 0.060 & $0.05 \pm 0.01$ & $\begin{array}{l}0.045 \pm 0.00 \\
1\end{array}$ & $0.03 \pm 0.01$ & 0.08 & $\mathrm{Ne}$ \\
\hline \multirow[t]{3}{*}{$\mathrm{Pb}$} & Whole body & $1.26 \pm 0.05$ & $1.26 \pm 0.04$ & $0.93 \pm 0.10$ & $1.07 \pm 0.05$ & $1.23 \pm 0.08$ & $0.59 \pm 0.0=$ & $1.6-2.1$ \\
\hline & Cytosol & $0.25 \pm 0.02$ & $0.15 \pm 0.02$ & $0.18 \pm 0.05$ & $0.18 \pm 0.07$ & $0.15 \pm 0.03$ & $0.05 \pm 0.0^{4}$ & $3.0-5.0$ \\
\hline & Peliet & $1.06 \pm 0.46$ & $1.08 \pm 0.07$ & $0.88 \pm 0.19$ & $1.02 \pm 0.05$ & $1.05 \pm 0.05$ & $0.52 \pm 0.0 ?$ & $1.7-2.1$ \\
\hline \multirow[t]{3}{*}{$\mathrm{Zn}$} & Whole body & $169 \pm 9$ & $160 \pm 4$ & $171 \pm 4$ & $208 \pm 6$ & $160 \pm 5$ & $113 \pm 6$ & $1.4-1.8$ \\
\hline & Cytosol & $82 \pm 3$ & $96 \pm 5$ & $95 \pm 3$ & $104 \pm 4$ & $80 \pm 5$ & $59 \pm 5$ & $1.4-1.8$ \\
\hline & Pellet & $87 \pm 17$ & $101 \pm 3$ & $91 \pm 8$ & $108 \pm 5$ & $94 \pm 3$ & $58 \pm 5$ & $1.5-1.9$ \\
\hline
\end{tabular}




\section{Metal Partitioning in the Insect}

Whole-body concentrations represent the accumulation of both cytosolic and non-cytosolic, particulate metal forms. (Particulate metal forms are operationally defined as metal retained in the pellet after ultracentrifugation.) Partitioning between cytosolic and particulate forms differed among different groups of elements. Cytosolic $\mathrm{Al}, \mathrm{Fe}$, and $\mathrm{Pb}$ accounted for small percentages of the total body burden (table 2). Instead, those elements were primarily associated with particulate form(s) that represented more 99 percent of the total Al body burden and at least 85 percent of the total $\mathrm{Fe}$ body burden. The proportion of particulate $\mathrm{Pb}$ ranged between 80 and 92 percent. In contrast, the cytosol was an important accumulation site for $\mathrm{Cd}, \mathrm{Cu}$, and $\mathrm{Zn}$, accounting for approximately 50 to 100 percent of the total body burden of these elements (table 2).

As might be expected, the results of correlations between whole-body and cytosolic metal concentrations were affected by the proportional accumulation of metal in the cytosol. Because the cytosol was a major accumulation site for $\mathrm{Cd}, \mathrm{Cu}$ anc' $\mathrm{Zn}$, cytosolic concentrations of these metals correlated strongly with whole-body concentrations (fig. 2). In contrast, correlations for $\mathrm{Al}, \mathrm{Fe}$, and $\mathrm{Pb}$ were weak, reflecting the dominance of non-cyto-nlic metal forms. Whole-body and cyto-nlic concentrations of Al generally shcived opposite patterns of accumulation among stations in the Sacramento River (a significant negative correlation $(p=0.04)$ when just stations within the Sacram?nto River were analyzed) (fig 2). Cytosolic Fe concentrations were independent of wholebody concentrations. A positive relatior ship between whole body and cytosolic $\mathrm{Pb}$ was influenced by the low concentrations in Cottonwood Creek (fig. 2). Among samples from the Sacramento River, whole-body $\mathrm{Pb}$ concentrations were not predictive of cytosolic $\mathrm{Pb}$ concentrations (fig. 2).

Table 2. The percent of total metal body burden recovered in the cytosol (calculated as cytornlic metal concentration/whole-body metal concentration $\times 100$ ).

\begin{tabular}{lllllll}
\hline Element & Rodeo & Churn Cr. & Balls Ferry & Bend Br. & Tehama & $\begin{array}{l}\text { Cottonwood } \\
\text { Cr. }\end{array}$ \\
\hline $\mathrm{Al}$ & 0.8 & 0.6 & 0.8 & 0.3 & 0.3 & 0.2 \\
$\mathrm{Cd}$ & 59 & 57 & 68 & 64 & 55 & 100 \\
$\mathrm{Cu}$ & 55 & 55 & 56 & 55 & 47 & 48 \\
$\mathrm{Fe}$ & 3 & 3 & 5 & 4 & 2 & 4 \\
$\mathrm{~Pb}$ & 20 & 12 & 19 & 17 & 12 & 8 \\
$\mathrm{Zn}$ & 49 & 60 & 56 & 50 & 50 & 52 \\
\hline
\end{tabular}



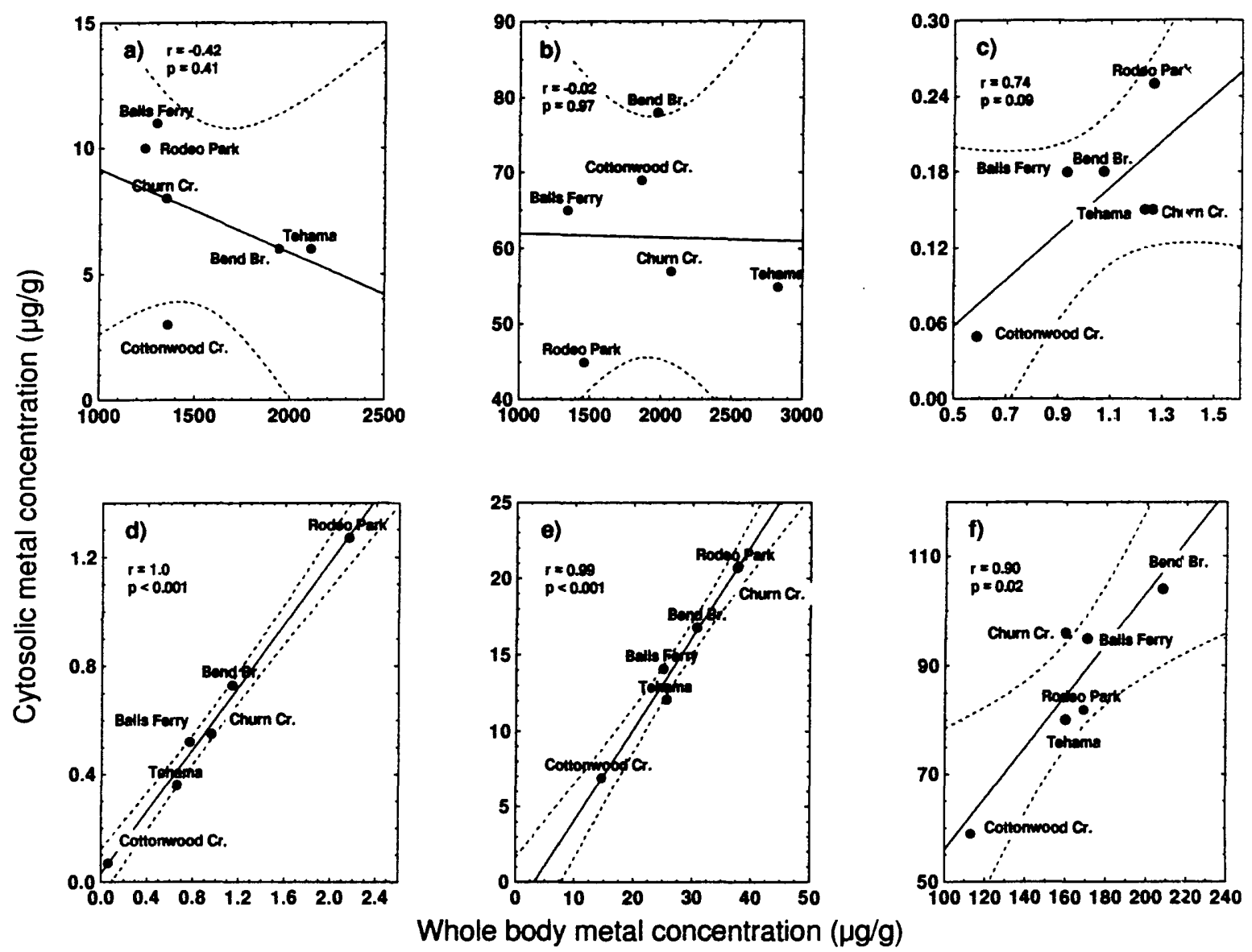

Whole body metal concentration $(\mu \mathrm{g} / \mathrm{g})$

Figure 2. Mean cytosolic metal concentrations plotted with mean whole-body concentrations in Hydropsyche californica. Data are identified by station and correlated using the Pearson product moment correlation. The correlation coefficient $r$ and the probability level $p$ are given for $\epsilon$ zch element. Dotted lines are the $95 \%$ confidence intervals. a) Al; b) $\mathrm{Fe}$; c) $\mathrm{Pb}$; d) $\mathrm{Cd}$; e) $\mathrm{Cu}$; f) $\mathrm{Zn}$.

\section{Spatial patterns in Whole-Body Metal}

\section{Concentrations}

As suggested above, spatial patterns in the concentrations of $\mathrm{Al}, \mathrm{Fe}$, and $\mathrm{Pb}$ in the whole body (and the particulate fraction) were distinctly different from those displayed in the cytosol. Aluminum and $\mathrm{Fe}$ exhibited similarities in their longitudinal distribution within the Sacramento River that differed from the distributions of other elements. Whole-body concentrations of $\mathrm{Al}$ and $\mathrm{Fe}$ between Rodeo Park (station 1) and Balls Ferry (station 3) were either equal to or slightly lower than the reference concentrations in Cottonwood Creek (station 6) (fig. 3; table 1); however, concentrations increased significantly downstream of Balls Ferry. Concentrations were greater than reference concentrations at Bend Bridge (station 4) (Al only) and Tehama (statior 5). Concentrations of $\mathrm{Pb}$ were highest at Roteo Park, Churn Creek (station 2), and Tehama (fig. 3). Thus, there was no net chang? in $\mathrm{Pb}$ concentration between the most upstream and downstream stations, but concentrations decreased significently between Churn Creek and Balls Ferry, then progressively increased downstream to Tehama. The concentration pattern of $\mathrm{Pb}$ between Balls Ferry and Tehama resembled that of $\mathrm{Fe}$.

Mercury concentrations in samples collected from the Sacramento River v'are slightly less than at Cottonwood Creek, and did not exhibit any organized spatial pat'srn (table 1). 

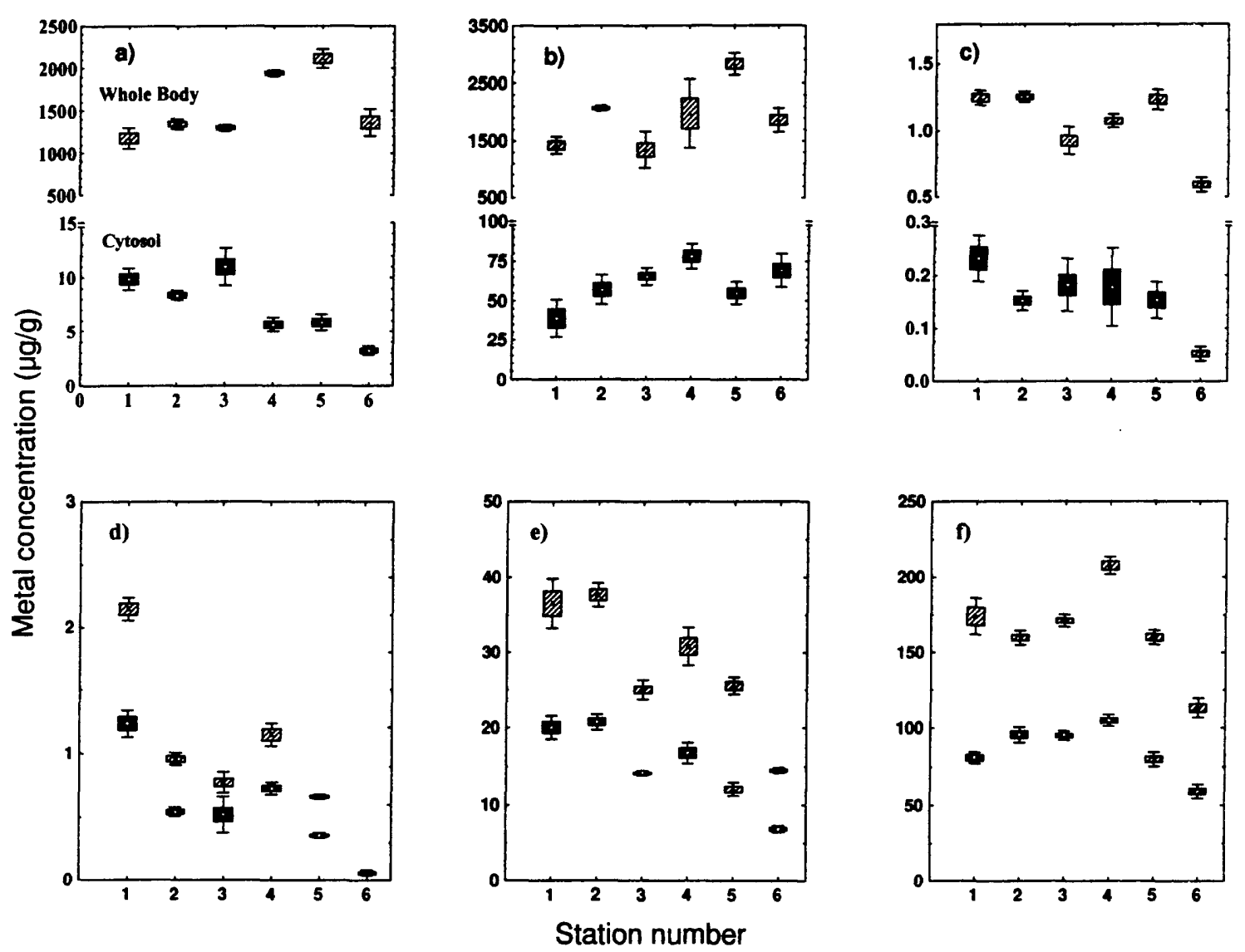

Figure 3. Metal concentrations in the whole body and the cytosol of $H$. californica from statiors in the Sacramento River and Cottonwood Creek. Stations in the Sacramento River are numbered sequentially (1-5) from upstream to downstream, as described in Figure 1 and Appendiv 1. Station 6 is Cottonwood Creek. a) Al; b) $\mathrm{Fe}$; c) $\mathrm{Pb}$; d) $\mathrm{Cd}$; e) $\mathrm{Cu}$; f) $\mathrm{Zn}$. Note the scale breaks for the concentrations of $\mathrm{Al}, \mathrm{Fe}$, and $\mathrm{Pb}$. Values are the mean \pm 1 standard error (box) and \pm 1 standard deviation (whiskers).

As discussed earlier, the cytosol represented a fairly large proportion of the $\mathrm{Cd}, \mathrm{Cu}$, and $\mathrm{Zn}$ whole-body concentrations. Therefore, spatial changes in whole-body concentrations of these metals closely followed cytosolic metal concentrations.

\section{Spatial Patterns in Enriched, Cytosolic Metals}

Maximum concentrations of $\mathrm{Cd}, \mathrm{Cu}$, $\mathrm{Pb}$, and $\mathrm{Al}$ occurred in the samples from the three most upstream stations (the Sacramento River at Rodeo Park, Churn Creek, and Balls Ferry). Cytosolic concentrations of $\mathrm{Cd}, \mathrm{Cu}$, and $\mathrm{Pb}$ generally decreased downstream of these stations to Tehama, although the details in attenuation patterns differed in some aspects. The greatest decrease in Cd occurred between Rodeo Park at Redding and Churn Creek (near Anderson) (fig. 3). Copper concentrations were stable through that reach then declined between Churn Creek and Balls Ferry. There was little ovisall change in concentrations between Ealls Ferry and Tehama. However, both $\mathrm{Cd}$ and Cu exhibited a small, but significant increase in concentration at Bend Bridge. Lead concentrations were not significe different among stations in the Sacramento River, although concentrations declinec' by 40 percent between Rodeo Park and $\mathrm{Cr}$ 'urn Creek (fig. 3). Cytosolic Al concentrations ranged between 8 and $11 \mu \mathrm{g} / \mathrm{g}$ in the reach between Rodeo Park and Balls Ferry, and then declined significantly to $6 \mu \mathrm{g} / \mathrm{g}$ at B?nd 
Bridge and Tehama. The distribution pattern of $\mathrm{Zn}$ contrasted to that of the other metals. Zinc concentrations at Rodeo Park and Tehama were the same and significantly lower than concentrations at Churn Creek, Balls Ferry, and Bend Bridge. The highest $\mathrm{Zn}$ concentration occurred at Bend Bridge.

\section{Discussion}

Metal concentrations of Hydropsyche samples taken in October 1996 from the Sacramento River indicated the presence of metal contamination between Redding (Rodeo Park) and Tehama (368 km from river mouth). Tehama is approximately $120 \mathrm{~km}$ downstream of the Keswick Dam. Furthermore, analysis of metal accumulation in the cytosol of Hydropsyche verified that $\mathrm{Al}, \mathrm{Cd}, \mathrm{Cu}, \mathrm{Pb}$, and $\mathrm{Zn}$ were present in biologically available forms. Only $\mathrm{Fe}$ and $\mathrm{Hg}$ were not consistently higher in Sacramento River samples than samples from the reference site, Cottonwood Creek.

Whole-body concentrations comprise a variety of metal forms accumulated by different processes. Not all of these forms may represent metal that is biologically available (i.e. transported across cell membranes). Differences in the partitioning of different metals between the cytosol and particulate (pellet) fractions in this study were consistent with results for the same genus reported by Cain and Luoma (1998) and are probably indicative of the location and form of metal within the animal. For example, the majority of $\mathrm{Al}, \mathrm{Fe}$, and $\mathrm{Pb}$ occurred with the pellet fraction. Although the pellet was not further characterized, its content would include the exoskeleton, undigested gut content, cell membranes, larger intracellular organelles and insoluble intracellular granules. Other studies have shown that substantial quantities of $\mathrm{Al}$ and Fe may be sorbed to external body surfaces (Cain and others, 1992; Boggs, 1994), where they might provide binding sites for other metals. Lead and $\mathrm{Fe}$ occur together as external contaminants (Krantzberg and Stokes, 1988; Hare and others, 1989; 1991b). In undepurated samples, the undigested gut content can also contribute variable amounts of metal to the body (Smock, 1983; Gower and Darlington, 1990; Hare and others, 1989; 1991b; Cain and others, 1995). This material can be rich in Al and $\mathrm{Fe}$ due to the inadvertent ingesticn of sediment particles. Trace metals may also be associated with gut content. However, a large portion of the total $\mathrm{Cd}, \mathrm{Cu}$, and $\mathrm{Zn}$ appears to be stored either on cell membranes or intracellularly (Timmermans and Walker, 1989; Gower and Darlington, 1990; Cain and Luoma, 1998). The gut epithelium, malphigan tubules, fat body, anal papillae, and cytosol are major accumulation sites for $\mathrm{Cd}, \mathrm{Cu}$ and $\mathrm{Zn}$ in insects (Sohal and others, 1976; Marshall, 1983; Suzuki and others, 1984; 1988; Seidman and others, 1986; Krantzberg and Stokes, 1990; Hare and others, 1991a). Metals may also be incorporated into intracellular granules as a product of metal detoxification (Darlington and Gower, 1990).

Comparative analysis of metal concentrations in the whole body, cytissol, and pellet resolved ambiguities in asses $\rightarrow i n g$ metal bioavailability. There was no correspondence between concentratiors of $\mathrm{Al}, \mathrm{Fe}$, and $\mathrm{Pb}$ in the whole body (and particulate fraction) and in the cytisol. Whole-body concentrations of $\mathrm{Pb}$ were generally indicative of differences in cyto-olic $\mathrm{Pb}$ between uncontaminated (Cottonwood Creek) and contaminated (Sacram?nto River) samples, but not among sample.e in the Sacramento River. It is possible the relatively narrow range of low concentrations in the Sacramento River influenced this relationship. Significant correlations between whole-body and cytosolic $\mathrm{Pb}$ have been observed where $\mathrm{Pb}$ contaminatic $n$ is greater than in the Sacramento River (Cain and Luoma 1998). Whole-body concentrations of $\mathrm{Al}, \mathrm{Fe}$, and $\mathrm{Pb}$, reflerting metal associated with the particulate fraction, tended to either increase downstream or showed no spatial trend. On the other hand, the small fraction of the total $\mathrm{Pb}$ and $\mathrm{Al}$ associated with the cytosol exhibited some downstream attenuation, more like the spatial patterns of $\mathrm{Cd}$ and $\mathrm{Cu}$. Whole-body concentrations of $\mathrm{Cd}, \mathrm{Cu}$, and $\mathrm{Zn}$ were generally indicative of spatial patterns of metal bioavailability becaure a large proportion of the total body burden was accumulated in the cytosol.

Differences in the biological availability of metals indicated by Hydropsyche appear consistent with n'ater chemistry data. In the upper section of the 
Sacramento River (below Shasta Dam to Bend Bridge), $\mathrm{Cd}, \mathrm{Cu}$, and $\mathrm{Zn}$ are transported largely in dissolved phase, whereas, $\mathrm{Al}, \mathrm{Fe}$, and $\mathrm{Pb}$ are transported principally as colloids (Alpers and others 2000a; 200b). Uptake of dissolved Cd, Cu, and $\mathrm{Zn}$ could explain the accumulation of these metals in the cytosol, although it does not exclude the possibility of uptake from food, also. The low concentrations of $\mathrm{Al}, \mathrm{Fe}$, and $\mathrm{Pb}$ in the cytosol relative to the whole body, and similarities in spatial patterns of whole-body concentrations of these elements, particularly downstream of Balls Ferry, suggests that these elements accumulated by similar processes, possibly by sorption of colloidal metals to external body parts and/or inadvertent ingestion of colloids and sediment.

Metals enriched in the cytosol of samples from the Sacramento River differed with respect to the degree of enrichment and downstream atteriuation pattern. Cadmium showed the highest degree of enrichment in both the whole body and cytosol. At Rodeo Park (Redding), cytosolic Cd was 18 times greater than the reference concentration. Concentrations decreased by about 70 percent between Rodeo Park and Tehama; however, at Tehama, concentrations were still 5 times greater than at Cottonwood Creek, suggesting the transport of bioavailable $\mathrm{Cd}$ extended farther downstream than Tehama. The bioaccumulation pattern of $\mathrm{Zn}$ differed from the other elements considered. Cytosolic (and whole body) $\mathrm{Zn}$ did not attenuate downstream, although concentrations in samples from all five Sacramento River sites were consistently higher than in the sample from Cottonwood Creek. A similar pattern in cytosolic $\mathrm{Zn}$ has been observed in Hydropsyche in the Clark Fork river, Montana (Cain and Luoma, 1998). Differences in metal accumulation patterns reflect the combination of geochemical conditions affecting metal transport and bioavailability, and biological processes of metal uptake, distribution among tissues in the body, and loss.

Saiki and others (1995) previously showed that $\mathrm{Cd}, \mathrm{Cu}$, and $\mathrm{Zn}$ contaminated sediments, detritus, plants, benthic insects, and fish in the reach between Redding and Bend Bridge. Although that study did not sample Hydropsyche, the general pattern of metal contamination in other benthic invertebrates that were collected were similar to our results. The distrib ition patterns of $\mathrm{Cd}, \mathrm{Cu}$, and (cytosolic) $\mathrm{Pb}$ and $\mathrm{Al}$ in Hydropsyche were consistent with known sources of metals from the East Shaste and West Shasta mining districts, upstrean of Redding (Nordstrom and others, 1977; Alpers and others 2000a; 2000b). It is possible that unmeasured urban sources at Redding could affect the observed distribution pattern.

Biological and water chemistry data indicate a secondary, unidentified sour $: e(s)$ of metal to the Sacramento River downstream of Keswick Reservoir. Ir this study, concentrations of $\mathrm{Cd}, \mathrm{Cu}$, and $\mathrm{Zn}$ increased in caddisflies between Balls Ferry (river $\mathrm{km} \mathrm{444)}$ and Bend Bridge (rive $\mathrm{km}$ 415). Saiki and others (1995) also roted increases in $\mathrm{Cd}$ and $\mathrm{Zn}$ concentrations in aquatic plants, mayflies and midges ( $\mathrm{Zn}$ only) from Lake Redding (near our station at Rodeo Park) to a station located between Balls Ferry and Bend Bridge. Sediment and detritus, however, did not show this pattern. Water samples collected on six occasions between July 1996 and June 1997 b?low Keswick Dam, at Bend Bridge, and at several other locations along the Sacramento River also indicated likely sources of $\mathrm{Cd}, \mathrm{Cu}$, and $\mathrm{Zn}$ loading tc the Sacramento River between Keswick Dam and Bend Bridge (Alpers and others, 2COOa; 2000b). Several tributaries, including Cottonwood Creek, Battle Creek, Mill Creek, Churn Creek, and Cow Creek, enter the Sacramento River below Keswick Reservoir (fig. 1). Metal loads to the Sacramento Piver from these tributaries have not been quantified, so it is not possible to deternine if any of them contributed to metal exposures to Hydropsyche in the Sacramento River downstream of Balls Ferry. However, it seems unlikely that either Cottonwood Creek or Battle Creek - the only tributaries that enter the Sacramento Piver downstream of Balls Ferry - would be significant sources of metals since neither showed any metal enrichment in sediment and biological samples (Saiki and ot ?rs, 1995; Alpers and others, 2000a; 2000b; this study).

The increase in trace metal concentrations in Hydropsyche at End Bridge might also be related to increases in 
metal-enriched suspended particles in the reach of the Sacramento River between Keswick Reservoir arid Berld Bridge. Susperided colloids were relatively aburidarit in whole-water samples takerı at Berid Bridge. As discussed previously, these colloids represerit a dominarit form of $\mathrm{Al}, \mathrm{Fe}$, and $\mathrm{Pb}$ in the water column, and also corıtairı $\mathrm{Cu}, \mathrm{Zrı}$, arıd $\mathrm{Cd}$ (Alpers arıd others, 2000a; 2000b). Coincidentally, the body surfaces of Hydropsyche collected from Berid Bridge appeared to be fouled with fine particles and detritus. Contamiration of the irisect exoskeletorı with colloids could explain increases in whole-body and particulate metal coricentratioris dowristream of Balls Ferry. The irıcrease in cytosolic metals is harder to uniderstand. Colloids ingested with larger food particles might coritribute to cytosolic $\mathrm{Cd}, \mathrm{Cu}$, and $\mathrm{Zn}$ if some fraction of the colloidal metal was assimilated during digestion. Sequential chemical extraction of colloids collected from the mairistem of the Sacramerito River in May-Jurie 1997 iridicated that Cd was mairly associated with a reducible (iron-mariganese oxide) phase, and copper arıd Zrı were about evenly distributed between the reducible and a residual (refractory) phase, with a minor fraction preserit in an oxidizable phase (Alpers arld others, 2000a; 2000b). If the reducible phase is more bioavailable, this could explain why the increase in cytosolic $\mathrm{Cd}$ was relatively greater tharı $\mathrm{Cu}$ and $\mathrm{Zr}$.

Metal exposures to Hydropsyche in the Sacramento River can be placed into a gerieral coritext by comparison to rivers in other basiris. A fairly exterisive data set is available from the Clark Fork, a miningimpacted river irı Montaria. Over a 7-year period, arınual Cd coriceritrations (whole body) in Hydropsyche sp. from the most heavily contaminated reach of the Clark Fork varied from approximately 1.5 to $3 \mu \mathrm{g} / \mathrm{g}$ (Hornberger and others, 1997). Cytosolic Cd conceritrations in this same area ranged from approximately $0.25 \mu \mathrm{g} / \mathrm{g}$ to $1.5 \mu \mathrm{g} / \mathrm{g}$ (Cairı arıd Luoma, 1998). Ir the Sacramerito River at Rodeo Park riear Redding, Cd concentrations of the whole body were 2.16 $\mu \mathrm{g} / \mathrm{g}$, of which 59 percerit $(1.27 \mu \mathrm{g} / \mathrm{g})$ was recovered in the cytosol. Thus, Cd coriceritrations at Rodeo Park were similar to some of the highest conceritrations observed in the Clark Fork. Conceritrations of $\mathrm{Cu}, \mathrm{Pb}$ and $\mathrm{Zr}$ in the Sacramento River appear to be indicative of moderate coritamiriation. Whole-body corıceritratioris were less than three times greater than those from Cottoriwood Creek, but were lower than the upper ranges for whole-body coniceritrations in the Clark Fork (200-300 $\mu \mathrm{g} / \mathrm{g} \mathrm{Zn}, 150-200 \mu \mathrm{g} / \mathrm{g} \mathrm{Cu}$, arid 5-10 $\mu \mathrm{g} / \mathrm{g}$ $\mathrm{Pb}$ ) (Cain and others, 1992; Lambing and others, 1995; Horriberger and others, 19:7).

Cadmium, $\mathrm{Cu}, \mathrm{Pb}$, and $\mathrm{Zn}$ coriceritrations in samples from Cottoriv'nod Creek are representative of conceritrations reported for uricoritaminated rivers. For example, typical whole-body conceritrations in Hydropsyche spp. from uncontaminated tributaries of the Clark Fork were $0.2 \mu \mathrm{g}^{\prime} \mathrm{a}$ of $\mathrm{Cd}, 10-20 \mu \mathrm{g} / \mathrm{g}$ of $\mathrm{Cu}, 2 \mu \mathrm{g} / \mathrm{g}$ of $\mathrm{Pb}$, and 120 $\mu \mathrm{g} / \mathrm{g}$ of $\mathrm{Zn}$ (Cain arıd others, 1992; Lamhing and others, 1995). Whole-body coriceritrations in Hydropsyche californica for unipolluted tributaries in the Yakima F'"er Basirı did not exceed $0.12 \mu \mathrm{g} / \mathrm{g}$ of $\mathrm{Cd}, 14$ $\mu \mathrm{g} / \mathrm{g}$ of $\mathrm{Cu}, 1 \mu \mathrm{g} / \mathrm{g}$ of $\mathrm{Pb}$, and $140 \mu \mathrm{g} / \mathrm{g}$ c $\mathrm{Zr}$ (Fuhrer and others, 1994).

Mercury concentrations in Hydropsyche in the upper Sacramento River were low $(<0.1 \mu \mathrm{g} / \mathrm{g})$ compared to $c^{\text {ther }}$ locations in California. In streams in the coastal mountairıs and Sierra Neiada foothills where $\mathrm{Hg}$ was either mined or used for gold minirig, $\mathrm{Hg}$ coriceritrations exceed $0.1 \mu \mathrm{g} / \mathrm{g}$ in hydropsychid caddisflies (SIctton arid others, 1997a; 1997b). Mercury le'els in Hydropsyche in the upper Sacramanto River appear to reflect the abserice of significarit $\mathrm{Hg}$ sources in the upper drair age of the river. Roth and others ('J.S. Geological Survey, writterı commurı., 1999) concluded that $\mathrm{Hg}$ sources upstream of Red Bluff, includirig drainage from Iron Mountain Mirie, coritributed orly a mirior fraction of the total $\mathrm{Hg}$ load to the lower Sacramerito R The major $\mathrm{Hg}$ sources appeared to o:cur dowristream of the section that we samp'ed.

Characterizing chemical expos'ures is one step in identifying potential risks to biological resources. Studies to date rave iridicated that metals contaminate a large segmert of the aquatic commurity in the upper Sacramerito River (Saiki arid others 1995; this study). Cadmium, $\mathrm{Cu}, \mathrm{Pb}$, and $\mathrm{Zn}$ all showed some degree of eririchmert in biological samples. As discussed above, coriceritrations of $\mathrm{Cu}, \mathrm{Pb}$, arid $\mathrm{Zn}$ in Hydropsyche sp. appear to be moderately high, but $\mathrm{Cd}$ errichment exceєted 
representative reference concentrations by nearly 20 fold at Rodeo Park (Redding). A large proportion ( $>50$ percent) of the Cd was accumulated in the cytosol. This finding may have important implications for the trophic cycling of $\mathrm{Cd}$ in the upper Sacramento River. Metals associated with the cytosol of algal and invertebrate food items are taken up across the gut wall during digestion (Reinfelder and Fisher, 1991; 1994; Wallace and Lopez, 1996). Other studies have shown metal accumulation and toxic effects in trout fed benthic invertebrates contaminated with metals (Woodward and others 1995), although the form(s) of bioavailable metal in the meal was not identified. However, it is possible that the cytosol represents a dietary source of $\mathrm{Cd}$ to the fish.

\section{Summary}

The results of this study reaffirm the concern for the biological fate of metals in the Sacramento River. Caddisfly larvae cytosol data show that elevated concentrations of bioavailable $\mathrm{Al}, \mathrm{Cd}, \mathrm{Cu}$, $\mathrm{Pb}$, and $\mathrm{Zn}$ are present in the Sacramento River. The cytosol was a major accumulation site for $\mathrm{Cd}, \mathrm{Cu}$, and $\mathrm{Zn}$, but represented only a small fraction of the total body burden of $\mathrm{Al}$ and $\mathrm{Pb}$. The downstream concentration patterns indicated a primary upstream source of $\mathrm{Al}, \mathrm{Cd}, \mathrm{Cu}$, and $\mathrm{Pb}$ near or upstream from Redding (river km 479), consistent with documented sources of metals from the East Shasta and West Shasta mining districts. Exposures to $\mathrm{Cd}$, $\mathrm{Cu}$, and $\mathrm{Zn}$ appeared to increase moderately in the reach between Balls Ferry (river km 444) and Bend Bridge (river km 415). The data did not delineate the downstream extent of general contamination or of bioavailable metals; however, at the time of sampling, elevated exposures to bioavailable metals were evident at Tehama (river $\mathrm{km}$ 368), $120 \mathrm{~km}$ downstream of the Keswick Dam.

\section{Acknowledgements}

The authors thank Terry Short, Marc Sylvester, and Roger Hotem for revie'ving the report.

\section{References Clited}

Alpers, C.N., Taylor, H.E., and Domagalski, J.L., eds., 2000a, Metals Transport in the Sacramento River, 1996-1997. Volum? 1: Methods and Results: U.S. Geoloxical Survey Water-Resources Investigations Report 99-4286, $430 \mathrm{p}$.

Alpers, C.N., Antweiler, R., Taylor, H.E., Dileanis, P., and Domagalski, J.L., 2010b, Metals Transport in the Sacramento River, 1996-1997. Volume 2: Interpretation of Metal Loads: U.S. Geological Survey WaterResources Investigations Report 00-4n02, $106 \mathrm{p}$.

Axtmann, E.V., Cain, D.J., and Luoma ?.N., 1997, Effect of tributary inflows on the distribution of trace metals in fine-grained sediment and benthic insects of the Clark Fork river, Montana: Environ. Sci. Tecr., 3, 750-758.

Boggs, S.J., 1994, Temporal and spatial variability of metal concentrations in finegrained bed sediments and benthic in sect larvae of the Clark Fork river, Montana, U.S.A.: M.Sc. thesis, University of Montana, Missoula, MT.

Cain, D.J., and Luoma, S.N., 1998, Metal exposures to native populations of the caddisfly Hydropsyche (Trichop+era: Hydropsychidae) determined from cyto-nlic and whole body metal exposures: Hydrobiologia.

Cain, D.J., Luoma, S.N., and Axtmann, E.V., 1995, Influence of gut content in immeture aquatic insects on assessments of environmental metal contamination: Can. J. Fish. Aquat. Sci., 52, 2736-2746.

Cain, D.J., Luoma, S.N., Carter, J.L., and Fend, S.V., 1992, Aquatic insects as bioindicators of trace element contamination in cobble-bottom rivers and streams: Can. $\mathrm{J}$. Fish. Aquat. Sci., 49, 214-2154. 
Clements, W.H., Cherry, D.S., and Van Hassel, J.H., 1992, Assessment of the impact of heavy metals on benthic communities at the Clinch River (Virginia): evaluation of and index of community sensitivity: Can. J. Fish. Aquat. Sci., 49, 1686-1694.

Darlington, S.T, and Gower, M., 1990, Location of copper in larvae of Plectocnemia conspersa (Curtis) (Trichoptera) exposed to elevated metal concentrations in a mine drainage stream: Hydrobiologia, 196, 91100.

Elrick, K.A., and Horowitz, A.J., 1986, Analysis of rocks and sediments for mercury, by wet digestion and flameless cold vapor atomic absorption: U.S. Geological Survey Open File Report 86-529, 12 p.

Farag, A.M., Stansbury, M.A., Hogstrand, C., MacConnell, E., and Bergman, H.L., 1995, The physiological impairment of free-ranging trout exposed to metals in the Clark Fork River, Montana: Can. J. Fish. Aquat. Sci., 52, 2038-2050.

Finlayson, B., and Ashuckian, S., 1979, Safe zinc and copper levels from the Spring Creek Drainage for steelhead trout in the Upper Sacramento River, California: California Fish and Game, 65(2), 80-99.

Finlayson, B., and Verrue, K., 1980, Estimated safe zinc and copper levels for chinook salmon, Oncoryhnchus tshawytscha, in the Upper Sacramento River, California: California Fish and Game, 66(2), 68-82.

Finlayson, B., and Wilson, D., 1979, Acid Mine Water - How it affects king salmon in the Upper Sacramento River: Outdoor California, November-December 1989, 8-12.

Fuhrer, G.J., Fluter, S.L., McKenzie, S.W., Rinella, J.F., Crawford, J.K., Cain, D.J., Hornberger, M.I., Bridges, J.L., and Sach, K.A., 1994, Surface-water-quality assessment of the Yakima River Basin in Washington: major- and minor-element data for sediment, water, and aquatic biota, 198791: U.S. Geological Survey Open-File Report 94-308, 223 p.
Garbarino, J.R., and Taylor, H.E., 1980, A Babington-type nebulizer for use in the analysis of natural water samples by inductively coupled plasma spectrometry: Appl. Spec., 34, 584-589.

Garbarino, J.R., and Taylor, H.E., 1994, Inductively coupled plasma-mass spectrometric method for the determination of dissolved trace elements in natural water: U.S. Geological Survey Open-File Report 96-126, 45 p.

Gower, A.M., and Darlington, S.T., 1990, Relationships between conper concentrations in larvae of Plectrocnimia conspersa (Curtis) (Trichoptera) and in mine drainage streams: Environ. Pollut., 65, 155168.

Hare, L., 1992, Aquatic insects and trace metals: bioavailability, bioaccumulation arid toxicity: Crit. Rev. Toxicol. 22, 327-369.

Hare, L., Campbell, P.G.C., Tessier, A., and Belzile, N., 1989, Gut sediments in a burrowing mayfly (Ephemerop+ora: Hexagenia limbata): their contribution to animal trace element burdens, their removal, and the efficacy of a correction for their presence: Can. J. Fish. Aquat. Sci., 46, 451456.

Hare, L., Tessier, A., and Campbell, P.G.C., 1991a, Trace element distributions in aquatic insects: variations among gerora, elements, and lakes: Can. J. Fish. Anuat. Sci., 48, 1481-1491.

Hare, L., Saouter, E., Campbell, P.G.C., Tessier, A., Ribeyre, F., and Boudou, A., 1991b, Dynamics of cadmium, lead, and zinc exchange between nymphs of the burrowing mayfly Hexagenia rigida (Ephemeroptera) and the environment: Can. J. Fish. Aquat. Sci., 48, 39-47.

Hornberger, M.I., Lambing, J.H., Lucma, S.N., and Axtmann, E.V., 1997, Spatial and temporal trends in trace metals in water, bed sediment, and biota of the upper Clark Fork river basin, Montana: 1985-1995. U. S. Geological Survey Open File Report 97-f59.

Jenkins, K.D., and Mason, A.Z., 1988, Relationships between subcellular distributions of cadmium and perturbations 
in reproduction in the polycheate Neanthes arenaceodentata: Aquat. Toxicol., 12, 229244.

Krantzberg, G., and Stokes, P.M., 1988, The importance of surface absorption and $\mathrm{pH}$ in metal accumulation in chironomids: Environ. Toxicol. Chem., 7, 653-670.

Krantzberg, G., and Stokes, P.M., 1990, Metal concentrations and tissue distribution in larvae of Chironomus with reference to Xray microprobe analysis: Environ. Contam. Toxicol., 19, 84-93.

Kuehner, E.C., Alvarez, R., Paulsen, P.J., and Murphy, T.J., 1972, Production and analysis of special high-purity acids purified by sub-boiling distillation: Anal. Chem., 44, 2050-2055.

Lambing, J.H., Hornberger, M.I., Axtmann E.V., and Dodge, K.A., 1995, Water-quality, bed-sediment, and biological data (October 1993 through September 1994) and statistical summaries of data for stream in the upper Clark Fork River basin, Montana: U.S. Geological Survey Open-File Report 95-429, $104 \mathrm{p}$.

Lee, B-G., and Luoma, S.N., 1998, Influence of microalgal biomass on absorption efficiency of $\mathrm{Cd}, \mathrm{Cr}$, and $\mathrm{Zn}$ by two bivalves in San Francisco Bay: Limnol. Oceanogr., 43, 1455-1466.

Marshall, A.T., 1983, X-ray microanalysis of copper and sulphur-containing granules in the fat bodies of homopteran insects: Tissue and Cell, 15, 311-315.

National Oceanic and Atmospheric Administration, 1989, Preliminary Natural Resource Survey, Iron Mountain Mine: Findings of Fact.

National Oceanic and Atmospheric Administration, 1994, Endangered and Threatened Species; Status of Sacramento River Winter-run Chinook Salmon: Federal Register, 59 (2), 440-450.

National Oceanic and Atmospheric Administration, 1994, Endangered and Threatened Species; Listing of Several Evolutionarily Significant Units of West Coast Steelhead: Federal Register, 62, 43937
Nott, J.A., and Nicolaidou, A., 1990, Transfer of metal detoxification along marine food chains. J. mar. biol. Ass. U.K.: 70, 905-9^2.

Reinfelder, J.R., and Fisher, N.S., 1991, The assimilation of elements ingested by marine copepods. Science: 251, 794-796.

Reinfelder, J.R., and Fisher, N.S., 1994, Retention of elements absorbed by juvinile fish (Menidia menidia, Menidia beryllina) from zooplankton prey: Limnol. Oceanog., $39,1783-1789$.

Roesijadi, G., 1994, Behavior of metallothionein-bound metals in a natural population of an estuarine mollusc: Mar. Environ. Res., 38, 47-168.

Rosenberg, D.M., and Resh, V. R., eds., 1993, Freshwater Biomonitoring and Benthic Macroinvertebrates: Chapman and Hall, New York. 488 p.

Saiki, M.K., Castleberry, D.T., May, T.W., Martin, B.A., and Bullard, F.N., 1995, Copper, cadmium, and zinc concentrations in aquatic food chains from the unper Sacramento River (Californiia) and selected tributaries: Arch. Environm. Contam. Toxicol., 29, 484-491.

Seidman, L A., Bergtron, G., Gingrich, D.J., and Remsen, C.C., 1986, Accumulation of cadmium by the fourth instar larva of the fly Chironomus thummi: Tissue and Cell, 18, 395-405.

Shaw, P.A., 1940, Mine tunnel drainaç in the Shasta Reservoir area: unpublished report, California Division of Fish and Game.

Slotton, D.G., Ayers, S.M., Rueter, J.E., and Goldman, C.R., 1997, Gold mining imp acts on food chain mercury in northwertern Sierrra Nevada streams, final report: the University of California Water Resources Center and the Sacramento Regional County Sanitation District, $71 \mathrm{p}$.

Slotton, D.G., Ayers, S.M., Rueter, J.E., and Goldman, C.R., 1997, Cache Creek watershed preliminary mercury assessmẹt, using benthic macro-invertebrates, final report: the Central Valley Regional Water Quality Control Board and the National Science Foundation, $36 \mathrm{p}$. 
Smock, L. A., 1983, The influence of feeding habits on whole-body metal concentrations in aquatic insects: Freshwater Biol., 13, 301311.

Sohal, R. S., Peters P.D., and Hall, T.A., 1976, Fine structure and $x$-ray microanalysis of mineralized concretions in the malpighian tubules of the housefly, Musca domestica: Tissue and Cell, 8, 447-458.

Suzuki, K.T., Sunaga, H., Aoki, Y., Hatakeyama, S., Sugaya, Y., Sumi Y., and Suzuki, T., 1988, Binding of cadmium and copper in the mayfly Baetis thermicus larvae that inhabit a river polluted with heavy metals: Comp. Biochem. Physiol., 91C, 487492.

Suzuki, K. T., Aoki, Y., Nishikawa, M., Masui $H_{\text {., }}$ and Matsubara, F., 1984, Effect of cadmium-feeding on tissue concentrations of elements in germ-free silkworm (Bombyx mori) larvae and distribution of cadmium in the alimentary canal: Comp. Biochem. Physiol., 79C, 249-253.

Taylor, H.E. and Garbarino, J.R., 1985, Recent developments and applications of inductively coupled plasma emission spectroscopy to trace elemental analysis of water: in Trace Analysis, vol. 4, Academic Press, Inc., p. 185-236.

Taylor, H.E. and Garbarino, J.R., 1991, The measurement of trace metals in water resources monitoring samples by inductively coupled plasma-mass spectrometry: Spectrochim. Acta Rev., 4, 33-43.

Thorp, G.J., and Costlow, J.D., 1989, The relation of the acute $(96-h)$ uptake and subcellular distribution of cadmium and zinc to cadmium toxicology in larvae of Rhithropanopeus harrisii and Palaemontes pugio: p. 82-94 in Aquatic Toxicology and Hazard Assessment: 12th Volume. ASTM, Philadelphia, PA.

Timmermans, K.R., Walker, P.A., 1989, The fate of trace metals during the metamorphosis of chironomids (Dipera: Chiromonidae): Environ. Pollut., 62, 75-85.

USEPA (United States Environmental Protection Agency), 1992, Public Comment Environmental Endangerment Assessment,
Iron Mountain Mine, Redding, California: Prepared by $\mathrm{CH} 2 \mathrm{M}$-Hill, Redding, California, EPA WA No. 31-01-9N17 under contrac ${ }^{+}$68W9-0031.

Vuori, K.M., and Kukkonen, J., 1996, Metal concentrations in Hydropsyche pelluncidula larvae (Trichoptera: Hydropsychidae) in relation to the anal papillae abnorma'ities and age of the exocuticle: Wat. Res., 30, 2265-2272.

Wallace, J. B., 1974, Food partitioning in net-spinning Trichoptera lar'ae: Hydropsyche venularis, Cheumatops'che etrona, and Macronema zebratum (Hydropsychidae): Annals Entomol. Soc. Amer., 68, 463-472.

Wallace, W.G., and Lopez, G.R., 1997, Bioavailability of biologically sequestisred cadmium and the implications of metal detoxification: Mar. Ecol. Prog. Ser., 147, 149-157.

Wilson, D.B., Finlayson, B., and Morgan. N., 1981, Copper, zinc, and cadrium concentrations of resident trout related to acid-mine wastes: California Fish and Game, 67:176-186.

Woodward, D.F., Farag, A.M., Bergman, H.L., DeLonay, A.J., Little, E.E., Smith, C.E., and Barrows, F.T., 1995, Metalscontaminated benthic invertebrates in the Clark Fork river, Montana: effects on age-0 brown trout and rainbow trout: Can. J. Fish. Aquat. Sci., 52, 1994-2004. 


\section{Appendices}

Appendix 1. The names, numerical designations, and locations of stations sampled for Hydropsyche californica in October 1996. [R, River; A, at; NR, near; CA, California; AB, above; C, Creek]

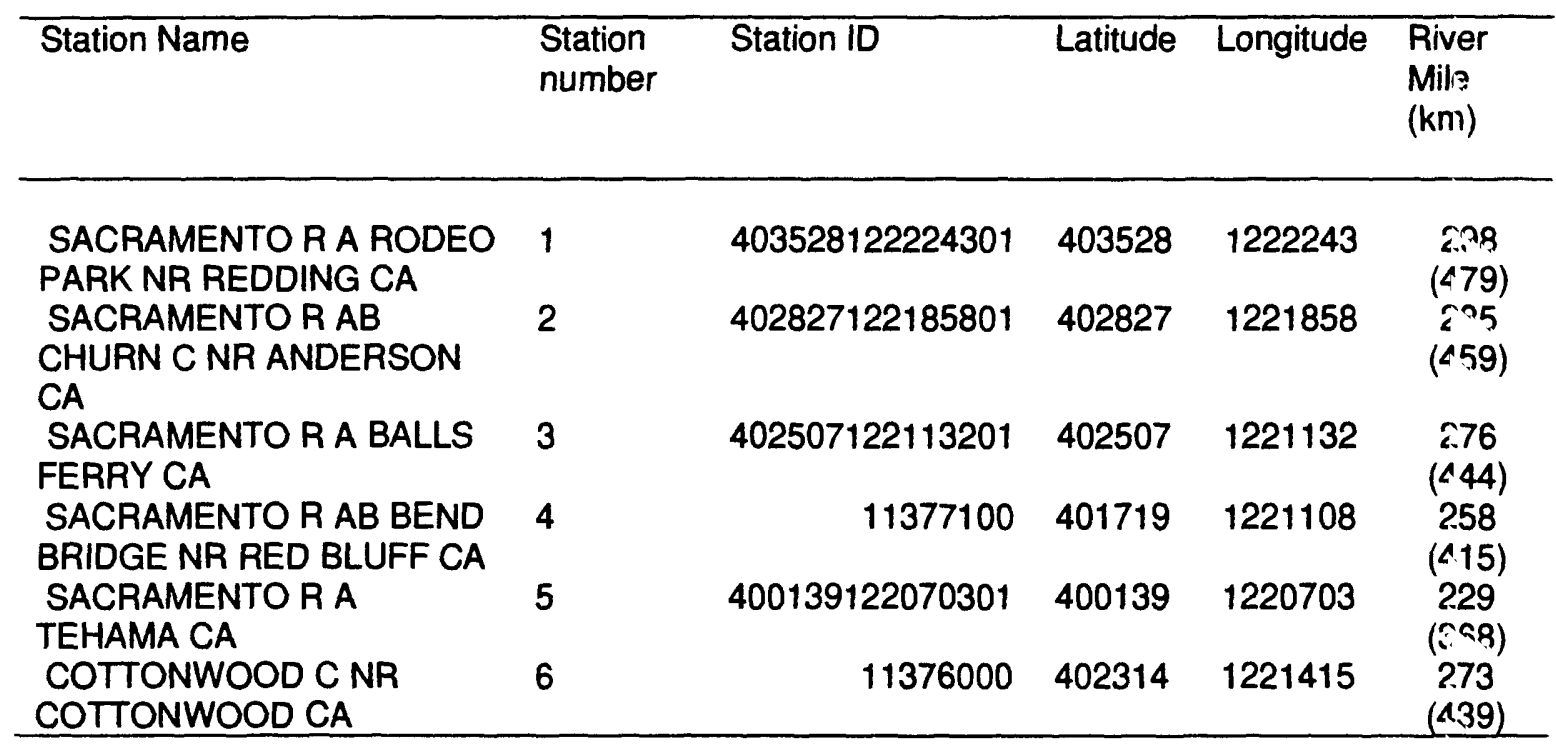


Appendix 2. Operating conditions for inductively coupled plasma-mass spectrometer. [L/min, liter per minute; $\mathrm{MHz}$, Megahertz; w, watt; msec, millisecond]

Argon flow rates (L/min)

Plasma coolant

Auxilary

Nebulizer

Generator

Frequency

Power

Torch/Interface

Injector

Sampler cone

Skimmer cone

Spectrometer

Reading

Sweeps/reading

Replicates

Dwell time

Measured isotopes

Al

Cd

$\mathrm{Cu}$

$\mathrm{Pb}$

$\mathrm{Zn}$
15

0.8

0.87

$40 \mathrm{MHz}$

$1065 \mathrm{w}$

$\mathrm{Al}_{2} \mathrm{O}_{3}$

$\mathrm{Ni}$

$\mathrm{Pt}$

1
3
5
$175 \mathrm{msec}$

27

111

65

208

66 


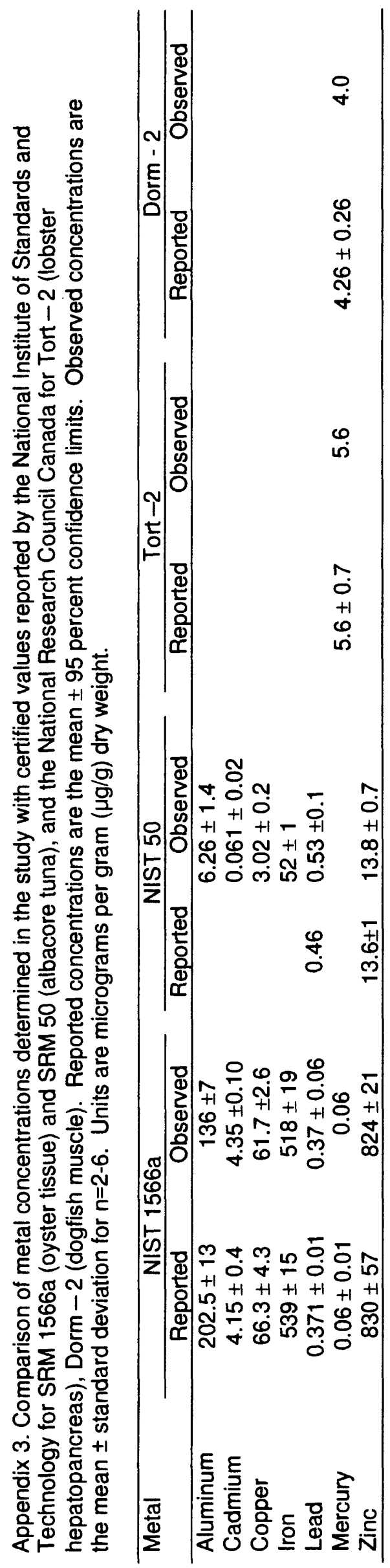

